\section{DIGITAL COMMONS \\ @ UNIVERSITY OF SOUTH FLORIDA}

\section{ABO: Interactive Journal for Women in the Arts, 1640-1830}

Volume 6

Issue 2 Volume 6.2 (Fall 2016)

Article 3

2016

\title{
Review of Rivka Swenson, Essential Scots and the Idea of Unionism in Anglo-Scottish Literature, 1603-1832
}

Rhona Brown

University of Glasgow, rhona.brown@glasgow.ac.uk

Follow this and additional works at: https://digitalcommons.usf.edu/abo

Part of the Dramatic Literature, Criticism and Theory Commons, Educational Methods Commons, Feminist, Gender, and Sexuality Studies Commons, and the Literature in English, British Isles Commons

\section{Recommended Citation}

Brown, Rhona (2016) "Review of Rivka Swenson, Essential Scots and the Idea of Unionism in AngloScottish Literature, 1603-1832," ABO: Interactive Journal for Women in the Arts, 1640-1830: Vol.6: Iss.2, Article 3.

http://dx.doi.org/10.5038/2157-7129.6.2.3

Available at: https://digitalcommons.usf.edu/abo/vol6/iss2/3

This Reviews is brought to you for free and open access by Digital Commons @ University of South Florida. It has been accepted for inclusion in ABO: Interactive Journal for Women in the Arts, 1640-1830 by an authorized administrator of Digital Commons @ University of South Florida. For more information, please contact digitalcommons@usf.edu. 
Review of Rivka Swenson, Essential Scots and the Idea of Unionism in AngloScottish Literature, 1603-1832

\author{
Abstract \\ Keywords \\ Scottish, Union, Anglo-Scottish literature \\ Creative Commons License \\ (c) $($ ) $\ominus$
}

Review: Rivka Swenson, Essential Scots and the Idea of Unionism in Anglo-Scottish Literature, 1603-1832

This work is licensed under a Creative Commons Attribution-No Derivative Works 3.0 License. 
Rivka Swenson. Essential Scots and the Idea of Unionism in Anglo-Scottish Literature, 1603 1832. Lewisburg, PA: Bucknell UP, 2016. Xviii + 348pp. ISBN: 9781611486797.

Reviewed by Rhona Brown

University of Glasgow, Scotland

Throughout the past thirty years in Scottish literary studies, there has been much talk of essentialism, with some critics championing the essential distinctiveness of Scottish literature from an encompassing English literature, and others rejecting the idea of an essential literary Scottishness or, indeed, Scottish identity, citing regional and linguistic variations, as well as perceived differences between Highland and Lowland Scotland and Scots. The recent general trend in Scottish literary studies has been towards the regional; towards what Hugh MacDiarmid called "our multiform, our infinite Scotland." Rivka Swenson's monograph, from its very title, embraces the idea of "essential Scots," as seen through the lens of Unionism and a series of adroit close readings and case studies. Swenson's argument takes a quotation from Locke as its starting point, and his question- - "since all things that exist are merely particulars, how come we by general terms?"- acts as a starting point not just for the book's thesis, but for Swenson's consideration of individual authors and texts. It is a confident monograph, and one which is likely to provoke much debate among scholars in the field.

Following the Referendum on Scottish independence in September 2014, unionism (or, more properly, the interrogation of unionism) has rarely been far from Scottish cultural commentators' minds and pens. In the aftermath of the "Brexit" vote in 2016, British Unionism is being questioned once more. These political debates are distant from literary discussions, but they revolve around many of the questions explored by Swenson in Essential Scots. They take it as read that there is something distinctive and essential about Scots; that, alongside Scotland's independent Church, educational and legal systems, Scots have an essential political identity. They remind us that, while just under half of Scots would reject the British Union, more than $60 \%$ are in favour of retaining European Union. This complex and often contradictory twenty-first-century political moment affects how Essential Scots will be read in Scotland now. The fact that the book's title utilises two politically charged terms"Unionism" and "Anglo-Scottish"-means that its arguments are inseparable from politics. Scotland in 2016 is a complicated place in political terms. The political "moments" of the book's chosen period-1603-1832 — are no less complicated. This complexity is certainly part of the book's appeal.

The fact that Swenson chooses to open her argument with 1603, and at the moment of monarchical union between Scotland and England, is welcome. 1707 is now a tired starting point, as literary critics and historians become more aware of the importance of preceding events. Recent scholarship has placed more emphasis on the so-called Glorious Revolution of 1688, but Swenson's introduction pays due attention to the fact that Scottish and English unification was a process of more than a century. However, although Swenson does treat the work of Francis Bacon in an opening chapter entitled "Writing Anglo-Scottish Unionism and its Discontents," there is little exploration of Scottish authors' response to the Union of 1603. This is, no doubt, beyond the scope of Essential Scots, but the analyses immediately following - of Defoe's role in the progress of the 1707 Union and the work of Tobias Smollett in the second half of the eighteenth century-demonstrate that this book is really concerned with post-1707 and, perhaps, post-1745 Scotland and Scottish literature, while monitoring what Swenson calls the "inheritances" of 1603. 
This is not a criticism per se; in fact, it is clear that the book's author is keen to shift the reader's gaze from the accepted Scottish literary icons of the long eighteenth century towards under-appreciated and under-researched figures. Hence, there is no extended discussion of poetry - perhaps because much of what is valued by today's scholars in the long eighteenth century is written in vernacular Scots and thus, while often constructed as essentialist in itself, is not easy to square with Unionism and Anglo-Scottishness - and only limited discussion of that figure so often seen as an "essential Scot," Robert Burns. Walter Scott, traditionally presented as a defining and influential "Anglo-Scot," makes an appearance here and there and prominently in the book's coda, but Swenson's emphasis is on moments of English-Scottish literary contact, or on those Scottish authors who engaged with Britishness in its various forms.

The book is divided into two parts: "Part I: Essential Scottishness and the Form of Original Anglo-Scottish Discontent" and "Part II: Unionism and the Challenge of the Individual in Early Nineteenth-Century Scottish Writing." These titles reveal a sub-argument in Swenson's thesis, that as Scotland moved along the road of "ever-closer Union" in the long eighteenth and early nineteenth centuries, the practical emphasis of literature moved away from the general and towards the particular; towards the individual. Swenson's chosen authors, texts, and exemplars demonstrate that arc very tidily, and reveal a narrative of the Scottish literary canon which is not always visible in the field's current scholarship.

Part I begins with a consideration of the work of Francis Bacon and Daniel Defoe in the context of "English Anxieties of Narration" and continues with "Writing Reunion, Rewriting Union for the Atomic Scot: Tobias Smollett's Travelling Types after the " 45 and Seven Years War" and "Writing Revolution as Essential Recovery: Samuel Johnson's Return to Scotland after Ossian." Replicating the approaches of Bacon and Defoe, Swenson conceives "of Britishness as a narrative progress, not just a legislative process but a coming-of-age story in which an Anglo-Scots dialectic would ultimately synthesize the Many as a (majority-Anglo) One" (26). For Swenson, echoing Thomas Kirke, "essential Scots" are recognised by their propensity to travel. The "travelling Scot" thus becomes an emblem throughout the book, from Smollett's Roderick Random and Expedition of Humphry Clinker to gendered representations in which "a masculinized Scottish traveler leaves behind a feminized Scottish homeland (or personification thereof) that pines and withers in consequence" (138). Johnson's journey, by contrast, reveals a vulnerable Scotland, ill at ease with its essential identity. Swenson considers contemporary Scotophobia with sensitivity in this section and elsewhere, but this discussion might have been enriched by reference to the contemporary battle for Britishness which played out between Smollett and John Wilkes.

Part II shines a light on a female author who is enjoying renewed critical attention, and a male author/editor who has received very little scholarly consideration. Chapter 4, "Individual Concerns, the Mock-Gothic, and Marriage Trouble: Anglo-Scottish SelfDifference in Susan Ferrier's Laboratory" follows the development of what Swenson calls "the emergent individual and the nascent British nation" through a case study not only of Ferrier's Marriage, an obvious allegory on union, but also The Inheritance and Destiny (3). The book's final chapter, "Describing the Subnational Hinge in 1822: Robert Mudie and the Aesthetic Politics of the Synthetic British Text" sheds welcome light on Mudie's work, but also on George IV's visit to Scotland in 1822, while looking towards Scots' role in colonising North America. The coda, entitled "Walter Scott and the Legacy of Chosen Scottishness," explores some of Scott's lesser-known texts and the Scottish "recovery plot." 
One of the book's highlights is the author's willingness to look beyond the literary text. Throughout the book, the reader is treated to apt and fascinating illustrations, from satirical cartoons on "Scotch Washing" and "Famine" to the floorplan and buffet designs for the ball held on George IV's visit to Edinburgh. These illustrations, along with the fulsome notes and bibliography, make this a valuable resource for the researcher.

The final chapter - and the book-ends on Scott's Menie, "the progeny of more than two hundred years' worth of stories about traveling Scots and the dynamic between essentialism and individuation within unionism" (247). It is not this book's role to bring these two seemingly contradictory strands into agreement. However, its sustained focus on the "dynamic" between the two, and its thoughtful consideration of the relationship between parts and wholes, the generalised and the particular, will add much to existing scholarship on Scottish literature of the long eighteenth century. 